\begin{tabular}{|c|c|c|}
\hline$\exists$ & $\begin{array}{c}\text { International Journal of Current Research in } \\
\text { Biosciences and Plant Biology }\end{array}$ & \\
\hline $\begin{array}{l}\text { EXCELLENT } \\
\text { PUBLISHERS } \\
\end{array}$ & 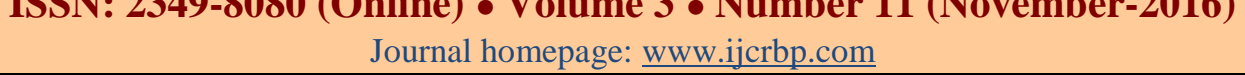 & \\
\hline
\end{tabular}

\title{
Decolourization Efficiency of Textile Dyes Using Peroxidase Enzyme Extracted from Raphanus sativus L. and Its Optimization Studies
}

\author{
P. Muthupriya ${ }^{*}$, M. Mugilan' ${ }^{1}$ and K. Sivakumar² \\ ${ }^{1}$ Department of Biotechnology, D.G. Vaishnav College, Chennai-6oo 106, Tamil Nadu, India \\ ${ }^{2}$ Department of Biotechnology, Karpaga Vinayaga College of Engineering and Technology, Chennai-6oo o24, \\ Tamil Nadu, India \\ *Corresponding author.
}

\begin{abstract}
A b stract
In the present study, the peroxidase enzyme was extracted from the tubers of Raphanus sativus L. and tested for their decolourization efficiency against reactive dyes. The extracted peroxidase was concentrated and purified by ion exchange chromatography. The optimum $\mathrm{pH}$ and temperature for the activity of the purified enzyme was found to be 6 and $37^{\circ} \mathrm{C}$ respectively. The molecular weight of the enzyme was determined as 44 $\mathrm{kDa}$ by SDS-PAGE analysis. The decolourization ability of peroxidase enzyme against dyes such as, Reactive blue 19 and Reactive yellow 12 were investigated. Maximum decolourization using enzyme was observed at $\mathrm{pH} 6$ and temperature $37^{\circ} \mathrm{C}$. The decolourization efficiency of the enzyme in the raw textile effluent was also determined. These present results suggest that the peroxidase extracted from $R$. sativus has great potential in the treatment of dyes present as pollutants in textile effluents.
\end{abstract}

\section{Article Info}

Accepted: 30 October 2016 Available Online: 06 November 2016

\section{Keywords}

Decolourization

Peroxidases

Raphanus sativus

Reactive dyes

Textile effluent

\section{Introduction}

The increase in world population, rapid urbanization and other industrialization activities has led to huge application of chemicals such as dyes in our day to day life. Major source of these dyes were from textile industries which utilizes it extensively and possess major threat to environment by releasing a significant portion via wastewater. Industries estimates that more than 10,000 different dyes and pigments were utilized and over 0.7 million tons of dyes of synthetic origin were produced every year (Campos et al., 2001; Rafi et al., 1990; Sathiya et al., 2007). Several physicochemical treatments have been utilized for the treatment of wastewaters generated from the dye industry including conventional techniques such as, flocculation, electrochemical process, coagulation, etc. (Gözmen et al., 2009). However these methods are limited due to high cost demand, huge sludge generation and tedious process (Rodríguez et al., 2010). Thus there is a need for alternative treatment techniques involving biotechnological aspects which gained importance in recent years (Palmieri et al., 2005). Several research has been performed in the last decades for the removal of dye based materials in the industrial wastewaters using microorganisms involving both aerobic and anaerobic process (Fu and Viraraghavan, 2001; Subashini et al., 2010). The major drawback of using microbes for degrading these pollutants is that it requires acclimatization process which is time consuming and the process also requires selective substrates in addition to the wastewaters (Movahedin et al., 2006). 
Peroxidases are the enzymes that act as an oxidoreductase and it is widely found in plants, microorganisms and vertebrates. Peroxidases are one of the key enzymes that plays important role in plant growth and differentiation (Saraiva et al., 2007). Peroxidases governs various cellular processes in plants including their rigidification of cell walls, auxin oxidation, senescence, organogenesis, phenol oxidation, cross-linking of cell wall proteins, salt stress tolerance, protection from pathogenic microorganisms (Sat, 2008; Şişecioğlu et al., 2010).

Different isoforms of peroxidase will be present within the same plant which can differ in their molecular mass, isoelectric point, substrate specificity, amino acid composition, etc. (Ikehata et al., 2005). Peroxidases assist in the enzymatic removal of $\mathrm{H}_{2} \mathrm{O}_{2}$ and their role is not clear as they catalyse large number of reactions (Kim and Lee, 2005).

Peroxidases are widely used in the clinical diagnosis and microanalytical immunoassays, synthesis of aromatic compounds and removal of peroxide from foods and industrial effluents (Aruna and Lali, 2001). One of the major problems faced by the textile industries are the lack of proper treatment for the decolourization of the reactive dyes in the effluents. Various reports were available claiming the role of peroxidases in the biotransformation of several organic molecules (Gülçin and Yildirim, 2005; Şişecioğlu et al., 2010). Peroxidases are widely distributed in the plant sources, but the genus, Raphanus serves as the major source for the commercial production of peroxidase. The radish ( $R$. sativus) is cultivated in most of the hill stations of Tamil Nadu. In the present study, the peroxides localized in the root tissues of $R$. sativus was purified by ion exchange chromatography and the purified peroxidase was used for the decolourization of textile dyes.

\section{Materials and methods}

\section{Extraction of peroxidases enzyme from $R$. sativus}

Fresh radish samples ( $R$. sativus) were collected, washed and drained. About $20 \mathrm{~g}$ of the radish tubers were homogenized in the mortar and pestle by adding phosphate buffer. The homogenate was filtered with the help of cheese cloth and the filtrate was centrifuged at $6000 \mathrm{rpm}$ for $15 \mathrm{~min}$ at $4^{\circ} \mathrm{C}$ (Gülçin, 2002). The pellet was discarded and the supernatant was taken as source of peroxidase enzyme which was used in the further studies.

\section{Peroxidase assay}

The crude protein fraction obtained from $R$. sativus was assayed for peroxidase enzyme according to the methods

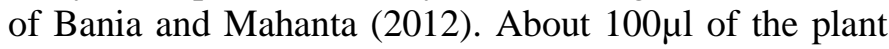
extract was added with $2 \mathrm{ml}$ of phosphate buffer ( $\mathrm{pH}$ 6.0) and $1 \mathrm{ml}$ of o-dianisidine solution. The reaction mixture was activated by adding $100 \mu 1 \mathrm{H}_{2} \mathrm{O}_{2}$ and the absorbance was read at $460 \mathrm{~nm}$ after $5 \mathrm{~min}$. The peroxidase activity was expressed as unit per $\mathrm{mg}$ of protein. The total protein content of the extract was determined by Lowry's method (Lowry, 1951).

\section{Purification and concentration of enzyme}

To $5 \mathrm{ml}$ of crude peroxidase obtained was added slowly with $20 \mathrm{ml}$ of $65 \%$ pre-cooled acetone $\left(-20^{\circ} \mathrm{C}\right)$ along the sides of the conical flask under constant stirring. After standing for $1 \mathrm{hr}$ at $-20^{\circ} \mathrm{C}$, the precipitated solution was centrifuged at $15,000 \mathrm{rpm}$ for $10 \mathrm{~min}$ at $10^{\circ} \mathrm{C}$. The supernatant was discarded and the pellet containing peroxidase was resuspended in $10 \mathrm{mM}$ phosphate buffer $(\mathrm{pH}$ 8). The acetone precipitated crude enzyme was dialyzed against $0.01 \mathrm{M}$ phosphate buffer for $3 \mathrm{hrs}$. The partially purified enzyme was further purified by ion exchange chromatography. The enzymatic fraction obtained by acetone precipitation was dissolved in $10 \mathrm{mM}$ phosphate buffer pH 6 and loaded on DEAE-cellulose column and eluted with $0.5 \mathrm{M} \mathrm{NaOH}$. The active fractions from the DEAE-cellulose column were concentrated and stored at $-4^{\circ} \mathrm{C}$ till further use (Maciel et al., 2007). The molecular weight of the purified peroxidase was determined by SDS-PAGE analysis (Laemmli, 1970).

\section{Optimization of $\mathrm{pH}$ and temperature for peroxidase activity}

The optimum $\mathrm{pH}$ responsible for the activity of purified peroxidase enzyme was determined by incubating the enzyme at different $\mathrm{pH}$ (5-10). After addition, the peroxidase activity was assayed by adding hydrogen peroxidase and pyrogallol and measuring absorption at $420 \mathrm{~nm}$. Similarly, the optimum temperature for the enhanced peroxidase activity was determined incubating the purified enzyme at different temperatures $(14,37,60$, 80,100 and $120^{\circ} \mathrm{C}$ ) and the enzyme activity was assayed as mentioned earlier (Mizobutsi et al., 2010).

\section{Dye decolourization studies}

Two reactive dyes (Reactive blue 19 and Reactive yellow 12) were selected for the present investigation. 
The stock solution of dyes was prepared by dissolving them separately in distilled water and $10 \mathrm{mg} / \mathrm{L}$ concentration of the dyes was prepared further. The reaction mixture consisting of $0.5 \mathrm{ml}$ of the purified peroxidase, $0.2 \mathrm{ml}$ of reactive dyes was incubated at $37^{\circ} \mathrm{C}$. The individual dye solution without enzyme served as control. The dye decolourization was assayed everyday by measuring the absorption at $640 \mathrm{~nm}$ using UV-Visible spectrophotometer. The decolourization experiments were carried out at different $\mathrm{pH}(5-10)$ and temperature $\left(14,37,60,80,100\right.$ and $\left.120^{\circ} \mathrm{C}\right)$ ranges to determine the optimum ranges.

\section{Results and discussion}

The peroxidase was extracted from $R$. sativus by homogenizing the tubers with phosphate buffer. The fresh roots of $R$. sativus gave the peroxidase with highest enzyme activity $(0.286 \mathrm{U} / \mathrm{mL})$ and protein content $(200$ $\mu \mathrm{g} / \mathrm{mL}$ ). The peroxidase obtained from $R$. sativus showed higher activity than that of the peroxidase obtained by Cochrane et al. (1999) who extracted enzyme from barley. Other reports are also available extracting peroxidase from plant sources including soybean seed coat (Sariri et al., 2003) and red beet (Rudrappa et al., 2005). In the present study, three step purification method was employed including acetone precipitation, dialysis and ion exchange chromatography.

Initially, the enzyme extracted from the $R$. sativus roots were precipitated with acetone and dialyzed against phosphate buffer. The acetone precipitation was used in enzyme precipitation as it is cheap and effective when compared with other existing methods. In a similar study, Rahman and their co-workers (1999) purified peroxidase from vegetable sources by acetone precipitation and purified the peroxidase enzyme with $1.9 \%$ purification fold. The acetone precipitation was followed by ion exchange chromatography with DEAECellulose column equilibrated with phosphate buffer. The fractions obtained were screened for peroxidase activity and the fraction with maximum activity was concentrated further. Of the number of columns used for ion exchange chromatography including DEAE sephadex, carboxy methyl cellulose, etc., DEAEcellulose is the most widely used column (Voet and Voet, 1990) due to its finer particle size and presence of high density microgranular cellulose which provides higher specificity (Jakoby, 1971).

Effect of $\mathrm{pH}$ was studied, where the peroxidase activity was increased when there was an increase in the $\mathrm{pH}$, until it reached to maximum activity at $\mathrm{pH} 6$, then it began to decrease (Fig. 1). It was observed that the purified peroxidase was active in weakly acidic $\mathrm{pH}$ and activity reduced in acidic and alkaline $\mathrm{pH}$ ranges. The differences in the enzyme activity with respect to $\mathrm{pH}$ might occur due to the alteration in the ionic state of enzyme and substrate. Also, it is essential to understand the optimum $\mathrm{pH}$ for the better affinity between enzyme and substrate (Wilder, 1962). The obtained results were similar to Lee et al. (1984) who found $\mathrm{pH} 6.5$ as the optimum $\mathrm{pH}$ for peroxidase obtained from broccoli. The peroxidases obtained from tobacco leaves, rice seedlings and strawberry fruits were found to be 6 (Mader et al., 1977), 5.7 (Padiglia et al., 1995) and 6 (Civello, 1995) respectively.

The enzyme reaction were carried out at different temperature ranges to determine the optimum temperature for the peroxidase extracted from $R$. sativus and the results were shown in Fig. 2. It is observed that there is increase in the peroxidase activity with the increase in the temperature and attains maximum at $37^{\circ} \mathrm{C}$, then it begin to decline with further increase in temperature. The results obtained were in line with that of Gisele et al. (2010) who observed the maximum peroxidase activity at $40^{\circ} \mathrm{C}$.

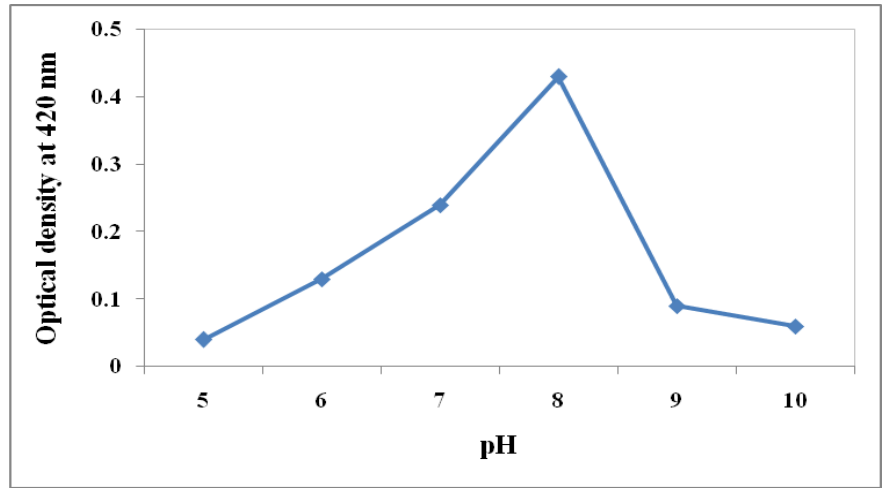

Fig. 1: Effect of $\mathrm{pH}$ on peroxidase activity.

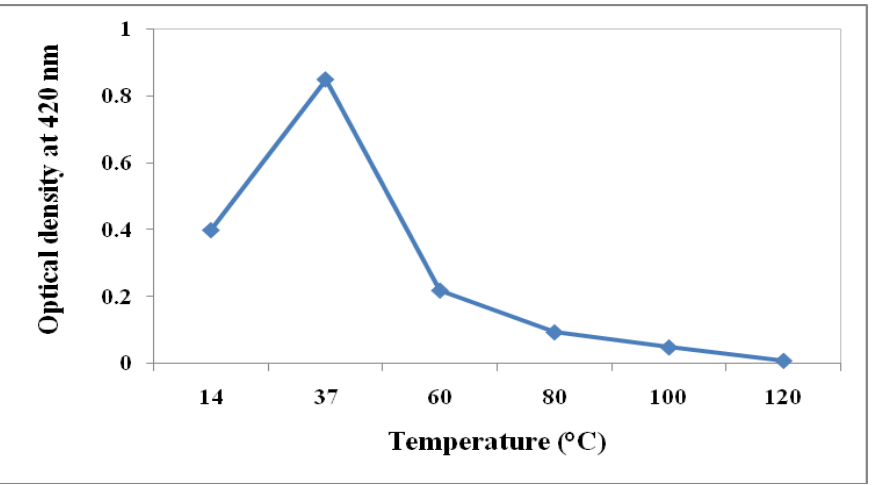

Fig. 2: Effect of temperature on peroxidase activity. 
The molecular weight of the purified peroxidase was determined using SDS-PAGE analysis. Four different bands with different molecular weight were observed in the resultant gel. Further purification is necessary to avail the pure peroxidase. The molecular weight of the bands obtained was determined as $66 \mathrm{kDa}, 45 \mathrm{kDa}, 36 \mathrm{kDa}$ and $14.4 \mathrm{kDa}$, respectively. Of the bands, the band corresponding to the $45 \mathrm{kDa}$ indicates the presence of peroxidase which was evidenced by Tabatabaie et al. (1998) who isolated peroxidase with molecular weight of $43 \mathrm{kDa}$. The results were in accordance with the results of Hermelinda et al. (2007), for peroxidases from Copaifera langsdorffii leaves which exhibited molecular weight of $58.1 \mathrm{kDa}$.

The efficiency of dye decolourization depends on the structure of dye and the redox-potential of the enzyme (Ratanapongleka and Phetsom, 2014). The ability of peroxidase from $R$. sativus to decolorize various structural dyes was examined. The dye decolourization ability of the purified peroxidase was tested against the commercial dyes, reactive blue 19, reactive yellow 12 and the raw textile effluent. The results revealed that the peroxidase efficiently decolourized the dyes up to $90 \%$ within three days of treatment. The rate of decolourization was increased from $24 \mathrm{hrs}$ of incubation and attained maximum of $100 \%$ during $90 \mathrm{hrs}$ of incubation for reactive blue 19 and $72 \mathrm{hrs}$ of incubation for reactive yellow 12, respectively. Whereas, in case of textile effluent maximum decolourization was attained during 48 hrs of incubation (Fig. 3), which is a promising result when compared to other conventional treatments for textile decolourization.

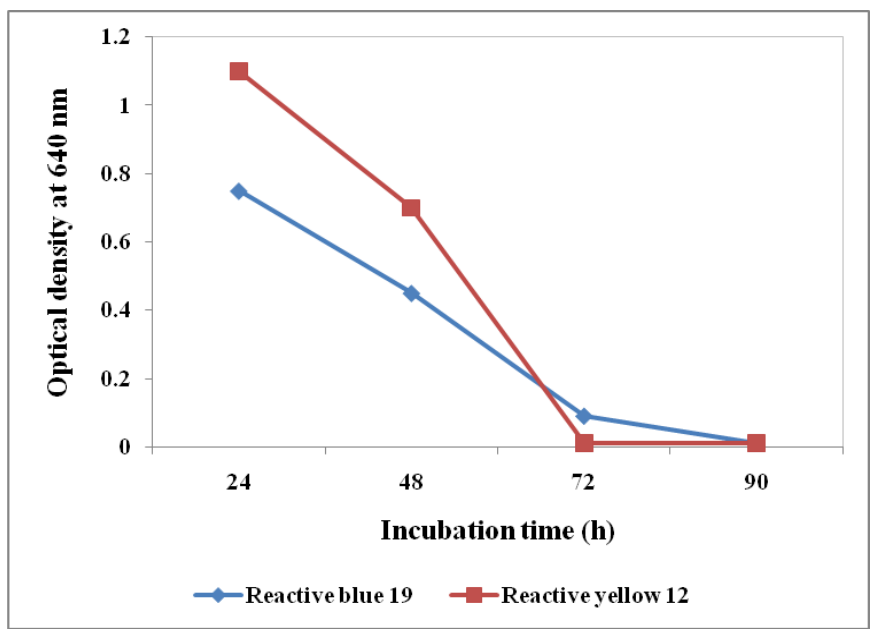

Fig. 3: Dye decolourization efficiency of peroxidase

The effect of $\mathrm{pH}$ on the dye decolourization of both the dyes was tested by adjusting the initial $\mathrm{pH}$ of the reaction medium. It is observed that the peroxidase decolourize both the dyes efficiently when the $\mathrm{pH}$ of the medium was maintained at 6 . The decolourization was considerably reduced before and after the optimum $\mathrm{pH}$ which indicates that the enzymes decolourize the dyes in weakly acidic conditions (Fig. 4). Since most of the textile effluents were weakly acidic and neutral in nature, the enzyme would have profound importance in their treatment.

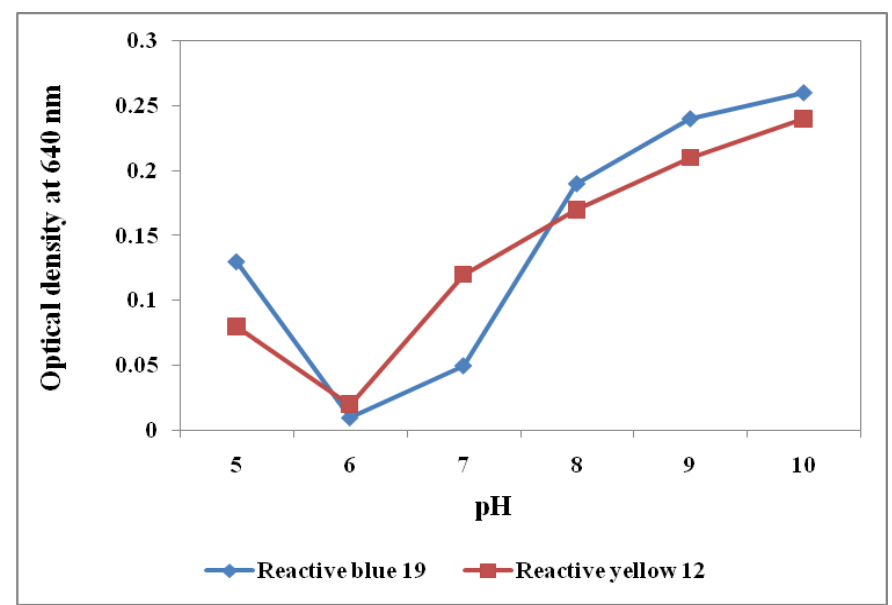

Fig. 4: Effect of $\mathrm{pH}$ on dye decolourization.

Next to $\mathrm{pH}$, the optimum temperature for the efficient dye decolourization by the peroxidase was determined by incubating the reaction mixture at different temperature. Of them, the reaction mixture incubated at $37^{\circ} \mathrm{C}$ was found to be efficient in the decolourization of both the dyes (Fig. 5). The peroxidase enzymes effectively decolourized the reactive dyes at mesophilic temperature. Hence, the enzyme can be employed for the treatment of textile effluent which would be economic and effective.

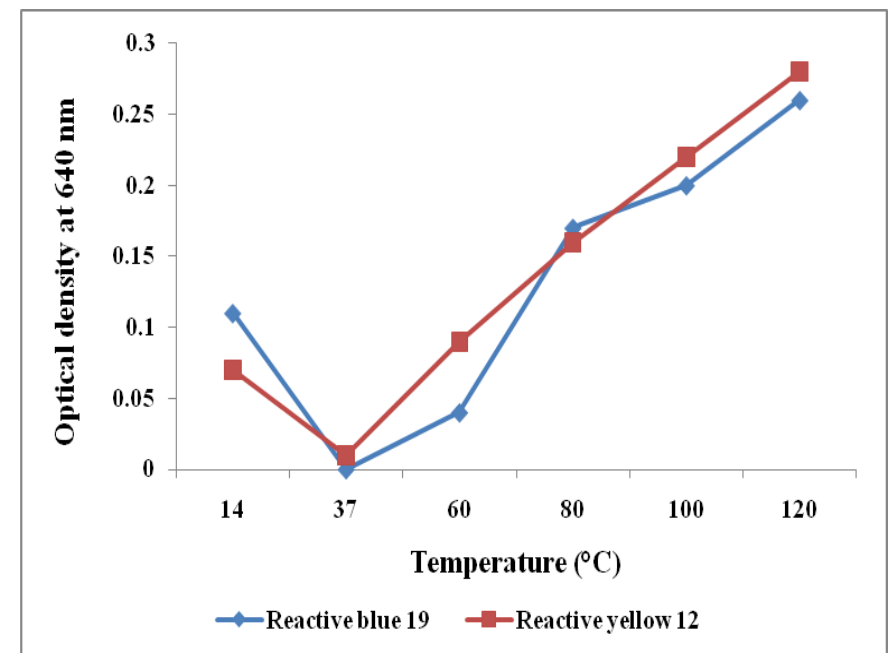

Fig. 5: Effect of temperature on dye decolourization. 


\section{Conclusion}

The results of the present study prove that $R$. sativus as a potential peroxidase source for biotechnological application. The decolourization of reactive dyes by partially purified peroxidase from $R$. sativus was determined. The peroxidase had an obvious potential to decolorize both the dyes within four days of incubation. It can be concluded that $R$. sativus roots served as an efficient source for peroxidase and the peroxidase serves as an effective enzyme for dye decolourization. The optimization of the treatment of textile effluents will be commenced in the further studies.

\section{Conflict of interest statement}

Authors declare that they have no conflict of interest.

\section{References}

Aruna, N., Lali, A., 2001. Purification of a plant peroxidase using reversibly soluble ion-exchange polymer. Process Biochem. 37(4), 431-437.

Bania, I., Mahanta, R., 2012. Evaluation of peroxidases from various plant sources. Int. J. Scient. Res. Publ. 2(5), 1-5.

Campos, R., Kandelbauer, A., Robra, K.H., Artur, C.P., Gubitz, G.M., 2001. Indigo degradation with purified laccases from Trametes hirsuta and Sclerotim rolfsii. J. Biotechnol. 8, 131-139.

Civello, P.M., Martinez, G.A., Chaves, A.R., Anon, M.C., 1995. Peroxidase from strawberry fruit; partial purification and determination of some properties. J. Agri. Food Chem. 43, 2596-2601.

Cochrane, M.P., Paterson, L., Gould, E., 1999. Changes in chalazal cell walls and in the peroxidase enzymes of the crease region during grain development in barley. J. Exp. Bot. 51(344), 507-520.

Fu, Y., Viraraghavan, T., 2001. Fungal decolorization of dye wastewaters: a review. Bioresour. Technol. 79(3), 251262.

Gisele, P. M., Fernando, L. F., Rosilene, A. R., Rolf, P., Ludmila, L., de Melo Neves, da Mota, W. F., 2010. Effect of $\mathrm{pH}$ and temperature on peroxidase and polyphenoloxidase activities of litchi pericarp. Sci. Agric. (Piracicaba, Braz.). 67(2), 213-217.

Gözmen, B., Kayan, B., Gizir, A. M., Hesenov, A., 2009. Oxidative degradations of reactive blue 4 dye by different advanced oxidation methods. J. Hazard. Mater. 168(1), 129-136.

Gülçin, İ., Yildirim, A., 2005. Purification and characterization of peroxidase from Brassica oleracea var. acephala. Asian J. Chem. 17, 2175-2183.

Hermelinda, P.F.M., Cação, C. M., Gouvêa, P., 2007. Extraction, purification and biochemical characterization of a peroxidase from Copaifera langsdorffii leaves. Quim.
Nova. 30(5), 1067-1071.

Ikehata, K., Buchanan, I.D., Pickard, M.A., Smith, D.W., 2005. Purification, characterization and evaluation of extracellular peroxidase from two Coprinus species for aqueous phenol treatment. Bioresour. Technol. 96, 17581770 .

Jakoby, W. B., 1971. Crystallization as a purification technique. Methods Enzymol. 22, 248.

Kim, S. S., Lee, D. J., 2005. Purification and characterization of a cationic peroxidase Cs in Raphanus sativus. J. Plant Physiol. 162(6), 609-617.

Laemmli, U.K., 1970. Cleavage of structural proteins during the assembly of the head of bacteriophage T4. Nature. 227, 680-685.

Lee, C. Y., Pennesi, A. P., Dickson, M. H., 1984. Characterization of Cauliflower peroxidase isoenzyme. J. Agric. Food Chem. 32(1), 18-21.

Lowry, O.H., Rosebrough, N.J., Farr, A.L., Randall, R.J., 1951. Protein measurement with the Folin phenol reagent. J. Biol. Chem. 193(1), 265-275.

Maciel, H. P. F., Gouvêa, C. M. C. P., Toyama, M., Smolka, M., Marangoni, S., Pastore, G. M., 2007. Extraction, purification and biochemical characterization of a peroxidase from Copaifera langsdorffii leaves. Quim. Nova. 30(5), 1067-1071.

Mader, M., Nessel, A., Bopp, M., 1977. On the physiological significance of the isoenzyme groups of peroxidase from tobacco demonstrated by biochemical properties. II. $\mathrm{pH}$ optima, Michaelis contstants, maximal oxidation rates. Plant Physiol. 82, 247-260.

Mizobutsi, G. P., Finger, F. L., Ribeiro, R. A., Puschmann, R., Neves, L. L. D. M., Mota, W. F. D., 2010. Effect of pH and temperature on peroxidase and polyphenoloxidase activities of litchi pericarp. Sci. Agric. 67(2), 213-217.

Movahedin, H., Shokoohi, R., Parvaresh, A., Hajia, M., Jafri, J. A., 2006. Evaluating the effect of glucose on phenol removal efficiency and changing the dominant microorganisms in the serial combined biological system. J. Health Sci. Resour. 6(2), 8-13.

Padiglia, A., Medda, R., Cruciani, E., 1995. Fractionation and characterization of two form of peroxidase from Oryza sativa. Prep. Biochem. 25(1\&2), 11-19.

Palmieri, G., Cennamo, G., Sannia, G., 2005. Remazol brilliant blue $\mathrm{R}$ decolourisation by the fungus Pleurotus ostreatus and its oxidative enzymatic system. Enz. Microb. Technol. 36(1), 17-24.

Rafi, F., Fraeankalin, W., Cerniglia, C. E., 1990. Azoreductase activity of anaerobic bacteria isolated from human intestinal microflora. Appl. Environ. Microbiol. 56, 21462151.

Rahman, U.K., Yaqub, M., Sheikh, M.A., Arshad, M., 1999. Extraction and evolution of peroxidase from various vegetable sources. Int. J. Agric. Biol. 1(3), 1560-8530.

Ratanapongleka, K., Phetsom, J., 2014. Decolorization of synthetic dyes by crude laccase from Lentinus polychrous Lev. Int. J. Chem. Eng. Appl. 5(1), 26-30.

Rodríguez, A., Ovejero, G., Sotelo, J. L., Mestanza, M., 
García, J., 2010. Heterogeneous fenton catalyst supports screening for mono azo dye degradation in contaminated wastewaters. Indust. Eng. Chem. Res. 49(2), 498-505.

Rudrappa, T., Neelwarne, B., Kumar, V., Lakshmanan, V., Venkataramareddy, S.R., Aswathanarayana, R.G., 2005. Peroxidase production from hairy root cultures of red beet (Beta vulgaris). Electr. J. Biotechnol. 8(2), 185-196.

Saraiva, J. A., Nunes, C. S., Coimbra, M. A., 2007. Purification and characterization of olive (Olea europaea L.) peroxidase-evidence for the occurrence of a pectin binding peroxidase. Food Chem. 101, 1571-1579.

Sariri, R., Najafi, F., Rezazadeh, A.L., 2003. Soybean seed coat contains higher peroxidase than other parts of the plant. Int. J. Chem. Sci. 1(2), 79-82.

Sat, I.G., 2008. The effect of heavy metals on peroxidase from Jerusalem artichoke (Helianthus tuberosus L.) tubers. Afr. J. Biotechnol. 7(13), 2248-2253.

Sathiya, M., Periyar, S., Sasikalaveni, A., Murugesan, K., Kalaichelvan, P.T., 2007. Decolorization of textile dyes and their effluents using white rot fungi. Afr. J. Biotechnol. 6(4), 424-429.

Şişecioğlu, M., Atasever, A., Şehitoğlu, M.H., Kaya, H.B., 2010. Purification and characterization of peroxidase from Turkish black radish (Raphanus sativus L.). J. Med. Plants Res. 4(12), 1187-1196.

Subashini, P., Yadav, R. H., Premalatha, M. S., 2010. Decolourisation of red $5 \mathrm{MB}$ dye by microbes isolated from textile dye effluent. J. Environ. Sci. Eng. 52(3), 213216.

Tabatabaie, Y. M., Khaleghparast, S., Nayebpour, S.M., 1998. Purification and partial characterization of peroxidases from cultivated Raphanus sativus L. var. cicil. Med. J. Islamic Republ. Iran. 12(3), 273-277.

Voet, D., Voet, J. G., 1990. Biochemistry. John Wiley and Sons, New York. 1223p.

Wilder, C.J., 1962. Factors affecting heat inactivation and partial reactivation of peroxidase purified by ion-exchange chromatography. J. Food Sci. 27(6), 567-573.

\section{How to cite this article:}

Muthupriya, P., Mugilan, M., Sivakumar, K., 2016. Decolourization efficiency of textile dyes using peroxidase enzyme extracted from Raphanus sativus L. and its optimization studies. Int. J. Curr. Res. Biosci. Plant Biol. 3(11), 79-84. doi: http://dx.doi.org/10.20546/ijcrbp.2016.311.012 